\title{
BEBERAPA FAKTOR RISIKO KETERLAMBATAN PERKEMBANGAN ANAK BALITA
}

\author{
Wafi Nur Muslihatun, Juli Widiyanto
}

Jurusan Kebidanan Poltekkes Kemenkes Yogyakarta Jurusan Keperawatan F-MIPA dan Kesehatan UMRI

\begin{abstract}
ABSTRAK
Anak-anak dengan keterlambatan perkembangan berisiko mempunyai capaian akademik rendah serta memiliki dampak substansial pada kesehatan dan fungsi pendidikan. Periode penting perkembangan anak adalah masa usia di bawah lima tahun (balita). Penelitian ini bertujuan untuk membuktikan beberapa faktor risiko keterlambatan perkembangan pada anak usia balita.Penelitian ini merupakan penelitian observasional dengan rancangan case control. Populasi studi adalah semua anak balita yang berkunjung ke Poliklinik Tumbuh Kembang RSUP dr. Sardjito Yogyakarta tahun 2012. Pengumpulan data dilakukan dengan wawancara terstruktur, observasi dan wawancara mendalam. Data dianalisis dengan uji chi-square dan multipel regresi logistik.Hasil penelitian menunjukan bahwa variabel yang terbukti berisiko terhadap keterlambatan perkembangan anak balita adalah riwayat asfiksia $(\mathrm{OR}=69,3 ; 95 \% \mathrm{C}=1,8$ $2655,7)$, riwayat gizi kurang $(\mathrm{OR}=19,5 ; 95 \% \mathrm{CI}=1,3-286,7)$, pemberian stimulasi kurang $(\mathrm{OR}=$ $17,1 ; 95 \% \mathrm{CI}=2,8-103,4)$ dan ibu bekerja $(\mathrm{OR}=16,4 ; 95 \% \mathrm{CI}=2,2-119)$, dengan nilai probabilitas sebesar $76,6 \%$. Disarankan untuk melakukan pencegahan dan penanganan cepat kejadian asfiksia, gizi kurang pada anak, pemberian stimulasi perkembangan yang baik dan meningkatkan interaksi ibu yang bekerja dengan anaknya.
\end{abstract}

Kata kunci: Keterlambatan Perkembangan, Balita

\section{PENDAHULUAN}

Keterlambatan atau gangguan atau penyimpangan perkembangan mencakup semua bentuk gangguan mental dan fisik atau kombinasi dari gangguan fisik dan mental yang terjadi sebelum seseorang mencapai usia dua puluh tahun, dapat terus berlanjut. ${ }^{(1)}$ Anak-anak dengan keterlambatan dan gangguan perkembangan memiliki dampak substansial pada kesehatan dan fungsi pendidikan anak-anak. Dampak substansial anak dengan gangguan perkembangan antara lain kunjungan dokter 1,5 kali lebih banyak; 3,5 kali lebih banyak masa perawatan di rumah sakit; dua kali lebih banyak jumlah hari sekolah yang hilang; dan peningkatan 2,5 kali lipat kemungkinan mengulang kelas di sekolah dibandingkan dengan anak tanpa kondisi ini. ${ }^{(2)}$ Hasil penelitian sebelumnya menyebutkan ada beberapa faktor yang mempengaruhi keterlambatan perkembangan anak. Riwayat asfiksia, Bayi Badan Lahir Rendah (BBLR), status gizi kurang, tingkat pendidikan ibu rendah, pekerjaan ibu, status ekonomi keluarga rendah, jarak kehamilan kurang dari 12 bulan, pemberian Air Susu Ibu (ASI) kurang dari 1 bulan, tidak ada riwayat diberi dongeng dalam 2 minggu, riwayat sepsis, riwayat hiperbilirubinemia, riwayat kejang demam, pemberian stimulasi, pekerjaan bapak dan lingkungan fisik merupakan faktor-faktor risiko keterlambatan perkembangan anak. ${ }^{(3-7)}$

Diperkirakan 200 juta anak-anak di dunia 
tidak mampu mencapai potensi perkembangan.(4) Penelitian tentang perkembangan anak di Yogyakarta tahun 1989 menunjukkan 14\% anak usia prasekolah dengan hasil Denver Developmental Sceening Test (DDST) abnormal.(8) Hasil penelitian tentang perkembangan anak di Kabupaten Bantul Yogyakarta pada tahun 2007 menunjukkan 28\% anak balita dengan perkembangan meragukan dan $8 \%$ anak kemungkinan mengalami perkembangan terlambat.(6) Berdasarkan data dari Instalasi Catatan Medik dan data kunjungan di Poliklinik Tumbuh Kembang RSUP dr. Sardjito Yogyakarta, pada tahun 2009 didapatkan $8,16 \%$ kasus anak dengan keterlambatan perkembangan. Pada tahun 2010 terjadi peningkatan kasus menjadi $14,85 \%$ kasus dan pada tahun 2011 ada $10,07 \%$ kasus anak dengan keterlambatan perkembangan.

Deteksi dini keterlambatan dan penyimpangan pertumbuhan dan perkembangan pada anak merupakan tema global utama dalam pelayanan kesehatan anak secara modern.(9) Rekomendasi dari komite ahli WHO tahun 2007 menyebutkan tentang perlunya penelitian untuk mengidentifikasi faktor-faktor risiko terjadinya keterlambatan perkembangan untuk dilakukan tindakan pencegahan.(4) Masa anak merupakan dasar pembentukan fisik dan kepribadian pada masa berikutnya. Usia anak sampai dengan lima tahun merupakan usia paling kritis. Dikatakan kritis karena usia tersebut merupakan suatu masa atau tahapan umur yang menentukan kualitas manusia pada usia selanjutnya. Pada masa kritis ini perkembangan kemampuan berbahasa, keativitas, kesadaran sosial, emosional dan intelegensia berjalan sangat cepat.(10-11) Penelitian ini bertujuan untuk membuktikan beberapa faktor risiko kejadian keterlambatan perkembangan pada anak usia balita di RSUP dr. Sardjito Yogyakarta.

\section{METODOLOGI PENELITIAN}

Penelitian ini merupakan penelitian analitik dengan rancangan case control. Penelitian ini menggunakan pendekatan retrospektif diawali dengan mengamati pada kelompok kasus (anak usia balita dengan keterlambatan perkembangan), kemudian dilanjutkan dengan kelompok pembanding kontrol (anak usia balita dengan perkembangan normal). Setelah mengamati kelompok kasus dan kelompok kontrol, jumlah angka terpajan dan tidak terpajan dari masing-masing kelompok kasus dan kontrol dianalisis dengan membandingkan frekuensi pajanan antara kedua kelompok tersebut. ${ }^{(12-15)}$

Penelitian dilakukan di Poliklinik Tumbuh Kembang RSUP dr. Sardjito Yogyakarta dari bulan April sampai dengan Mei 2012. Populasi studi pada penelitian ini adalah semua anak usia balita yang berkunjung ke Poliklinik Tumbuh Kembang RSUP dr. Sardjito Yogyakarta tahun 2012.

Sampel dalam penelitian ini adalah anak usia balita (usia 12-59 bulan), sehat dengan perkembangan normal dan suspek mengalami keterlambatan perkembangan yang datang ke Poliklinik Tumbuh Kembang RSUP dr. Sardjito Yogyakarta. Besar sampel dalam penelitian ini menggunakan derajat kemaknaan (Confident Interval/CI) 95\%, dihitung berdasarkan nilai OR dan p2 hasil penelitian sebelumnya sesuai dengan sembilan variabel yang diteliti. Besar sampel minimal dihitung menggunakan rumus: ${ }^{(16)}$

$$
n=\frac{\left[Z_{1-\alpha / 2} \sqrt{2 \bar{p}(1-\bar{p})}+Z_{1-\beta} \sqrt{\left(p_{1}\left(1-p_{1}\right)\right)+\left(p_{2}\left(1-p_{2}\right)\right)}\right]^{2}}{\left(p_{1}-p_{2}\right)^{2}}
$$

Diperoleh hasil 35 sampel dengan perbandingan kasus: kontrol = $1: 1$. Pengambilan sampel penelitian menggunakan metode nonrandom baik terhadap sampel kasus maupun sampel kontrol secara 
purposive sampling, dengan tetap memperhatikan kriteria inklusi dan eksklusi. Kriteria inklusi sampel kasus dan kontrol adalah sebagai berikut: Anak balita sehat yang berkunjung ke poliklinik tumbuh kembang RSUP dr. Sardjito, diklasifikasi mengalami suspek keterlambatan perkembangan atau perkembangan normal, memiliki ibu yang bersedia menjadi responden dibuktikan dengan penandatanganan lembar informed consent dan mampu berkomunikasi.

Data penelitian terdiri dari:

a. Data sekunder, berupa data demografi dan data kesehatan balita kelompok kasus dan kelompok kontrol dari catatan rekam medik pasien.

b. Data primer, setelah diperoleh data demografi dan data kesehatan balita, dilakukan observasi dan wawancara langsung kepada orang tua/pengasuh anak balita. Observasi dilakukan terhadap hasil pemeriksaan perkembangan anak balita menggunakan lembar Denver II untuk mengetahui status perkembangan anak balita, skor APGAR untuk mengetahui riwayat asfiksia,(17) berat badan lahir untuk mengetahui riwayat BBLR(3) dan Tinggi Badan/Umur anak untuk mengetahui riwayat gizi kurang.(18) Wawancara langsung dilakukan untuk mendapatkan informasi secara lebih rinci tentang pemberian ASI,(19) tingkat pendidikan ibu, ibu bekerja dan pengeluaran keluarga untuk pemenuhan nutrisi anak.(20) Data pengetahuan ibu tentang perkembangan anak dikumpulkan dengan kuesioner yang diadopsi dari kuesioner Caregiver Knowledge of Child Development Inventory (CKCDI).(21) Data pemberian stimulasi perkembangan dikumpulkan dengan instrumen/kuisioner yang dikembangkan dari pedoman stimulasi perkembangan anak dan lembar Denver II.(22-23).

c. Data kualitatif, diperoleh dari $10 \%$ responden dari kelompok kasus dan kelompok kontrol melalui indepth interview untuk mendapatkan informasi yang mendalam tentang keterlambatan perkembangan dan faktor-faktor yang terbukti berpengaruh terhadap keterlambatan perkembangan anak dari variabel-variabel yang diteliti.

Analisis data pada penelitian ini dilakukan menggunakan alat bantu komputer dengan program SPSS for windows terdiri dari: analisis univariat, analisis bivariat, analisis multivariat. Analisis univariat dilakukan dengan cara membuat distribusi frekuensi dari setiap variabel. Analisis bivariat dilakukan untuk menguji hubungan antara dua variabel yaitu masing-masing variabel independen dan variabel dependen. Uji statistik yang digunakan adalah uji chi square dengan menghitung OR. Tingkat kepercayaan ditentukan $\mathrm{p}=0,05$ dengan $\mathrm{CI}$ 95\%. Analisis multivariat untuk melihat hubungan variabel-variabel independen dengan variabel dependen serta mengetahui variabel independen yang paling besar hubungannya dengan variabel dependen. ${ }^{(24)}$ Uji regresi logistik digunakan untuk menjelaskan hubungan variabel independen dengan variabel dependen. Data kualitatif yang diperoleh melalui indept interview dilakukan analisis isi (content analysis). Penelitian ini telah mendapatkan persetujuan untuk dilaksanakan (ethical clearance) dari Komite Etik Penelitian Kesehatan Fakultas Kedokteran Universitas Diponegoro Semarang tertanggal 13 April 2012.

\section{HASIL DAN PEMBAHASAN}

Poliklinik Tumbuh Kembang RSUP dr. Sardjito Yogyakarta adalah suatu unit 
pelayanan kesehatan paripurna meliputi tindakan promotif, preventif, kuratif dan rehabilitatif yang ditangani oleh Tim ahli dari berbagai disiplin ilmu dan profesi. Poliklinik Tumbuh Kembang RSUP dr. Sardjito Yogyakarta bertujuan untuk memfasilitasi agar proses tumbuh kembang seorang anak berlangsung secara baik dan optimal. Pelayanan yang tersedia di Poliklinik Tumbuh Kembang RSUP dr. Sardjito Yogyakarta antara lain klinik laktasi, klinik balita, klinik usia sekolah dan remaja, klinik gizi, klinik genetika, klinik gigi, pemeriksaan general check up anak serta konsultasi psikologi.

Dari data kunjungan Poliklinik Tumbuh Kembang RSUP dr. Sardjito Yogyakarta tanggal 9 April sampai dengan 1 Mei 2012 terdapat 131 kunjungan anak balita. Dari jumlah tersebut 79 di antaranya adalah anak usia balita (12-59 bulan) dan dilakukan pemeriksaan perkembangan oleh dokter menggunakan formulir Denver II. Ada sembilan anak yang tidak memenuhi kriteria inklusi dan eksklusi sehingga tidak disertakan sebagai sampel penelitian karena menderita retardasi mental, epilepsi, riwayat menderita kelainan jantung bawaan, cerebral palsy, penyakit berat yaitu nefrotik sindrom dan meningo-ensefalitis.

Tabel 1 menunjukkan bahwa jumlah anak yang memiliki riwayat mengalami asfiksia neonatorum lebih banyak pada kelompok kasus $(25,7 \%)$ dibanding anak pada kelompok kontrol (2,9\%). Sebanyak $22,9 \%$ anak kelompok kasus memiliki riwayat BBLR (<2.500 gram), dan hanya 2,9\% anak pada kelompok kontrol memiliki riwayat BBLR. Lebih banyak anak pada kelompok kasus $(65,7 \%)$ yang tidak diberikan ASI Eksklusif ( $<6$ bulan), dibanding anak pada kelompok kontrol yang tidak diberikan ASI Eksklusif (34,3\%). Jumlah anak yang mempunyai riwayat mengalami gizi kurang lebih banyak pada kelompok kasus $(34,3 \%)$ dibanding anak pada kelompok kontrol $(2,9 \%)$. Ibu yang memiliki pendidikan rendah lebih banyak terdapat pada kelompok kasus $(11,4 \%)$ dibanding pada kelompok kontrol $(5,7 \%)$. Lebih banyak ibu pada kelompok kontrol yang berpengetahuan tinggi $(42,9 \%)$ dibanding ibu pada kelompok kasus $(5,7 \%)$. Ibu yang bekerja lebih banyak terdapat pada kelompok kasus $(68,6 \%)$ dibanding pada kelompok kontrol (54,3\%). Pengeluaran untuk nutrisi anak < Rp 305.036/bulan pada kelompok kasus sedikit lebih banyak $(45,7 \%)$ dibanding pengeluaran untuk nutrisi anak pada kelompok kontrol (40\%). Sebanyak $71,4 \%$ anak kelompok kasus kurang mendapatkan stimulasi perkembangan $(<80 \%)$, dan hanya $14,3 \%$ anak pada kelompok kontrol kurang mendapatkan stimulasi perkembangan.

Tabel 1. Analisis Univariat Kelompok Kasus dan Kontrol Keterlambatan Perkembangan Kelompok Kasus dan Kontrol di Poliklinik Tumbuh Kembang RSUP dr. Sardjito Yogyakarta

\begin{tabular}{|c|c|c|c|c|c|c|}
\hline \multirow{2}{*}{ Karakteristik } & \multicolumn{2}{|c|}{ Kasus } & \multicolumn{2}{|c|}{ Kontrol } & \multicolumn{2}{|c|}{ Total } \\
\hline & n & $\%$ & n & $\%$ & $\mathbf{N}$ & $\%$ \\
\hline \multicolumn{7}{|l|}{ Riwayat Asfiksia } \\
\hline - Asfiksia & 9 & 25.7 & 1 & 2.9 & 10 & 14.3 \\
\hline - $\quad$ Tidak Asfiksia & 26 & 74.3 & 34 & 97.1 & 60 & 85.7 \\
\hline \multicolumn{7}{|l|}{ Riwayat BBLR } \\
\hline Mean & 3012.29 & & 3132.00 & & 3072.14 & \\
\hline Standar Deviasi & 487.570 & & 312.615 & & 411.011 & \\
\hline Minimum & 1900 & & 2400 & & 1900 & \\
\hline Maksimum & 4100 & & 3900 & & 4100 & \\
\hline - $\quad$ BBLR & 8 & 22.9 & 1 & 2.9 & 9 & 12.9 \\
\hline - $\quad$ Tidak BBLR & 27 & 88.1 & 34 & 97.1 & 61 & 87.1 \\
\hline
\end{tabular}




\begin{tabular}{|c|c|c|c|c|c|c|}
\hline \multirow{2}{*}{ Karakteristik } & \multicolumn{2}{|c|}{ Kasus } & \multicolumn{2}{|c|}{ Kontrol } & \multicolumn{2}{|c|}{ Total } \\
\hline & n & $\%$ & n & $\%$ & & $\%$ \\
\hline \multicolumn{7}{|l|}{ Pemberian ASI kurang } \\
\hline Mean & 2.74 & & 4.83 & & 3.79 & \\
\hline Standar Deviasi & 2.811 & & 2.022 & & 2.648 & \\
\hline Minimum & 0 & & 0 & & 0 & \\
\hline Maksimum & 6 & & 6 & & 6 & \\
\hline - Tidak ASI Eksklusif & 23 & 65.7 & 12 & 34.3 & 35 & 50 \\
\hline - ASI Eksklusif & 12 & 34.3 & 23 & 65.7 & 35 & 50 \\
\hline \multicolumn{7}{|l|}{ Riwayat gizi kurang } \\
\hline - Gizi kurang & 12 & 34.3 & 1 & 2.9 & 13 & 18.6 \\
\hline - Gizi baik & 23 & 65.7 & 34 & 97.1 & 57 & 81.4 \\
\hline \multicolumn{7}{|l|}{ Pendidikan ibu rendah } \\
\hline - Rendah & & 11,4 & 2 & 5.7 & 6 & 8.6 \\
\hline - $\quad$ Tinggi & 31 & 88.6 & 33 & 94.3 & 64 & 91.4 \\
\hline \multicolumn{7}{|c|}{ Pengetahuan ibu tentang perkembangan anak } \\
\hline Mean & 49.129 & & 61,500 & & 55.314 & \\
\hline Standar Deviasi & 14.303 & & 15.556 & & 16.089 & \\
\hline Minimum & 25 & & 37.5 & & 25 & \\
\hline Maksimum & 77.5 & & 90 & & 90 & \\
\hline $\begin{array}{ll}\text { - } & \text { Rendah } \\
\text { - } & \text { Tinggi }\end{array}$ & $\begin{array}{c}33 \\
2\end{array}$ & $\begin{array}{c}94.3 \\
5.7\end{array}$ & 20 & $\begin{array}{l}57.1 \\
42.9\end{array}$ & $\begin{array}{l}53 \\
17\end{array}$ & $\begin{array}{l}75.7 \\
24.3\end{array}$ \\
\hline Ibu bekerja & & & & & & \\
\hline - Bekerja & 24 & 68,6 & 19 & 54,3 & 43 & 61,4 \\
\hline - Tidak Bekerja & 11 & 31,4 & 16 & 45.7 & 27 & 38.6 \\
\hline \multicolumn{7}{|c|}{ Pengeluaran untuk kebutuhan nutrisi anak } \\
\hline - $\quad<\operatorname{Rp} 305.036 /$ bulan & 16 & 45.7 & 14 & 40 & 30 & 42.9 \\
\hline - $\quad \geq \operatorname{Rp} 305.036 /$ bulan & 19 & 54.3 & 21 & 60 & 40 & 57.1 \\
\hline \multicolumn{7}{|c|}{ Pemberian stimulasi perkembangan kurang } \\
\hline Mean & 60.71 & & 90.97 & & 75.84 & \\
\hline Standar Deviasi & 23.684 & & 11.866 & $=$ & 24.041 & \\
\hline Minimum & 18 & & 57 & & 18 & \\
\hline Maksimum & 100 & & 100 & $=$ & 100 & \\
\hline - $\quad$ Kurang & 25 & 71.4 & 5 & 14.3 & 30 & 42.9 \\
\hline - Baik & 10 & 28.6 & 30 & 85.7 & 40 & 57.1 \\
\hline
\end{tabular}

Hasil penelitian ini membuktikan bahwa adanya riwayat asfiksia berhubungan dengan keterlambatan perkembangan pada anak usia balita ( $p$-value $<0,05$ ) dengan nilai OR 11,8, 95\%CI 1.4-98.8. Faktor lain yang berhubungan dengan keterlambatan perkembangan pada anak usia balita adalah: adanya riwayat BBLR (OR 10.1, 95\%CI 1.285.6); Pemberian ASI kurang (tidak diberikan ASI eksklusif) (OR 3.7, 95\%CI 1.4-9.9); Riwayat gizi kurang berhubungan dengan keterlambatan perkembangan pada anak usia balita (OR 17,7. 95\%CI 2.2-145.9);
Pengetahuan ibu tentang perkembangan anak rendah (OR 12.4, 95\% CI 2.6-59.9); Pemberian stimulasi perkembangan kurang (OR 15, 95\%CI 4.5-49.7) (Tabel 2).

Hasil uji regresi logistik menunjukkan bahwa riwayat asfiksia adalah faktor risiko yang paling kuat terhadap keterlambatan perkembangan anak usia balita (Tabel 3). Risiko keterlambatan perkembangan tidak dipengaruhi oleh pendidikan ibu rendah dan pengeluaran keluarga untuk kebutuhan nutrisi anak rendah. 
Tabel 2. Analisis Bivariat Faktor-faktor yang Berpengaruh pada Keterlambatan Perkembangan Anak Usia Balita di Poliklinik Tumbuh Kembang RSUP dr. Sardjito Yogyakarta

\begin{tabular}{|c|c|c|c|c|c|c|c|}
\hline \multirow{2}{*}{ Faktor Risiko } & \multicolumn{2}{|c|}{ Kasus } & \multicolumn{2}{|c|}{ Kontrol } & \multirow{2}{*}{ OR } & \multirow{2}{*}{ 95\% CI } & \multirow{2}{*}{$p$-Value } \\
\hline & $\mathbf{n}$ & $\%$ & $\mathbf{n}$ & $\%$ & & & \\
\hline Riwayat Asfiksia & & & & & & & \\
\hline - Asfiksia & 9 & 25.7 & 1 & 2.9 & 11.8 & $1.4-98.8$ & $0.006 *$ \\
\hline - Tidak Asfiksia & 26 & 74.3 & 34 & 97.1 & & & \\
\hline Riwayat BBLR & & & & & & & \\
\hline - $\quad$ BBLR & 8 & 22.9 & 1 & 2.9 & 10.1 & $1.2-85.6$ & $0.014 *$ \\
\hline - Tidak BBLR & 27 & 88.1 & 34 & 97.1 & & & \\
\hline Pemberian ASI kuran & & & & & & & \\
\hline - Tidak ASI Eksklusif & 23 & 65.7 & 12 & 34.3 & 3.7 & $1.4-9.9$ & $0.009 *$ \\
\hline \begin{tabular}{lll} 
- & \multicolumn{3}{l}{ ASI Eksklusif } \\
& Riyawat Gizi
\end{tabular} & 12 & 34.3 & 23 & 65.7 & & & \\
\hline$(\mathrm{TB} / \mathrm{U})$ & 12 & 34,3 & & 2.9 & & $2.2-145.9$ & $0.001 *$ \\
\hline $\begin{array}{ll}\text { - } & \text { Gizi kurang } \\
\text { - } & \text { Gizi baik } \\
\text { Pendidikan }\end{array}$ & & 65,7 & 34 & 97.1 & & & \\
\hline $\begin{array}{ll}\text { - } & \text { SD, SMP } \\
\text { - } & \text { SMA, Perguruan } \\
\text { Pengetahuan Ibu }\end{array}$ & $\begin{array}{c}4 \\
31\end{array}$ & $\begin{array}{l}11.4 \\
88.6\end{array}$ & $\begin{array}{c}2 \\
33\end{array}$ & $\begin{array}{c}5.7 \\
91.4\end{array}$ & 2.1 & $0.4-12.5$ & 0.337 \\
\hline - Rendah & 33 & 94.3 & 20 & 57.1 & 12.4 & $2.6-59.9$ & $0.000 *$ \\
\hline $\begin{array}{ll}- & \text { Tinggi } \\
& \text { Ibu Bekerja }\end{array}$ & 2 & 5.7 & 15 & 42.9 & & & \\
\hline - Bekerja & 24 & 68.6 & 19 & 54,3 & 1.8 & $0.7-4.9$ & 0.220 \\
\hline - Tidak Bekerja & 11 & 31.4 & 16 & 45.7 & & & \\
\hline anak/bulan & 16 & 45.7 & 14 & 40 & 1.3 & $0.5-3.3$ & 0.629 \\
\hline - $\quad<\operatorname{Rp} 305.036,00$ & 19 & 54.3 & 21 & 60 & & - & \\
\hline $\begin{array}{l}\text { - } \quad \text { PRp 305.036,00 } \\
\text { Pemberian Stimulasi }\end{array}$ & & & & & & $=$ & \\
\hline - Kurang & 25 & 71.4 & 5 & 14.3 & 15 & $4.5-49.7$ & $0.000 *$ \\
\hline - Baik & 10 & 28.6 & 30 & 85.7 & & $x^{2}$ & \\
\hline
\end{tabular}

Tabel 3. Model Akhir Analisis Multivariat dengan Metode Backward LR Beberapa Faktor Risiko Keterlambatan Perkembangan Anak Usia Balita di Poliklinik Tumbuh Kembang RSUP dr. Sardjito

\section{Pembahasan.}

Hasil penelitian ini membuktikan bahwa terdapat empat variabel yang secara bersamasama terbukti kuat sebagai faktor risiko terjadinya keterlambatan perkembangan anak usia balita, yaitu riwayat asfiksia, riwayat gizi kurang, pemberian stimulasi perkembangan kurang dan ibu bekerja. Asfiksia adalah masalah umum yang dapat mengakibatkan defisit perkembangan saraf, dan pada gilirannya akan mengganggu anak yang sedang berkembang. Asfiksia perinatal dianggap salah satu yang utama penyebab cedera otak dan cacat perkembangan saraf di kemudian hari pada bayi cukup bulan. ${ }^{(25-27)}$ Hasil penelitian ini sejalan dengan hasil penelitian sebelumnya oleh Moura $\mathrm{DR}^{(4)}$ yang menyebutkan bahwa nilai APGAR menit ke lima kurang dari tujuh merupakan faktor risiko terjadinya suspek keterlambatan perkembangan pada anak usia antara 12 dan 24 bulan. Anak-anak dengan riwayat nilai 
APGAR menit ke lima kurang dari tujuh menunjukkan risiko lima kali lebih tinggi untuk mengalami suspek keterlambatan perkembangan atau Suspect Development Delay (SDD) dan empat kali lebih tinggi menetap dalam kondisi ini dibandingkan dengan anak-anak yang riwayat nilai APGAR menit ke lima mencapai tujuh atau lebih. Hasil penelitian ini juga sejalan dengan penelitian oleh Elenjickal $\mathrm{MG}^{(28)}$ yang menunjukkan bahwa bayi baru lahir mengalami asfiksia berat dikategorikan sebagai bayi baru lahir risiko tinggi. Tingginya risiko pada bayi baru lahir berhubungan signifikan dengan keparahan keterlambatan perkembangan

Gizi sangat berperan pada periode kritis pertumbuhan otak yaitu pada triwulan terakhir kehamilan sampai dengan tiga tahun pertama kehidupan, yang sering disebut sebagai windows of opportunity. Kekurangan gizi selama masa kritis perkembangan anak akan menyebabkan penurunan jumlah sel-sel otak yang akan mengganggu pertumbuhan otak kurang gizi dapat menyebabkan penurunan sebanyak $20-30 \%$ sel-sel otak dan $15-25 \%$ jumlah plasmogen (zat penting untuk myelin) pada substansi alba otak. ${ }^{(11)}$ Kekurangan gizi pada masa bayi dan anak usia dini memberikan efek yang merugikan pada perkembangan kognitif dan perilaku anak-anak. Indeks $\mathrm{TB} / \mathrm{U} \quad<-2 \quad z$ score (stunting) menunjukkan kegagalan pertumbuhan yang linear dan disebabkan oleh kurangnya asupan gizi dan infeksi sebelum dan sesudah kelahiran. Stunting pada awal kehidupan anak berhubungan dengan lemahnya perkembangan kognitif, motorik dan sosial emosional serta meningkatkan angka kematian. Pertumbuhan janin terhambat atau stunting pada usia dua tahun pertama kehidupan meningkatkan kerusakan yang ireversibel termasuk pemendekan tubuh pada usia dewasa, kemampuan sekolah lebih rendah dan berisiko terkena penyakit kronis yang berhubungan dengan nutrisi. ${ }^{(29-31)}$ Hasil penelitian ini sesuai dengan penelitian Walker $\mathrm{SP}^{(32)}$ yang menyebutkan bahwa anak dengan riwayat gizi kurang mempunyai risiko tiga kali lebih besar mengalami keterlambatan perkembangan dibanding anak yang tidak ada riwayat gizi kurang dan penelitian oleh Sitaresmi $\mathrm{dkk}^{(6)}$ yang menyebutkan bahwa anak status gizi kurang merupakan faktor risiko keterlambatan perkembangan anak.

\section{Perkembangan} memerlukan stimulasi/rangsangan khususnya stimulasi dalam keluarga. Stimulasi dalam keluarga yang dapat diberikan antara lain berupa penyediaan alat mainan, sosialisasi anak, keterlibatan ibu dan anggota keluarga lain terhadap kegiatan anak serta perlakuan ibu terhadap perilaku anak. Anak yang banyak mendapatkan stimulasi terarah akan cepat berkembang dibanding anak yang kurang atau bahkan tidak mendapatkan stimulasi. Stimulasi juga dapat berfungsi untuk penguat perkembangan anak. ${ }^{(19)}$ Hasil penelitian ini sesuai dengan penelitian Hastuti( ${ }^{(33)}$ yang membuktikan bahwa pengasuhan stimulasi psikososial yang diberikan ibu kepada anak di rumah memberikan pengaruh positif pada perkembangan fisik dan motorik anak. Penelitian oleh Briawan $^{(34)}$ juga menyimpulkan bahwa pemberian stimulasi berkorelasi dengan nilai perkembangan anak.

Ibu bekerja cenderung memiliki waktu yang kurang untuk memberikan stimulasi perkembangan pada anak, sehingga anak cenderung mengalami keterlambatan perkembangan. Hasil penelitian ini sejalan dengan penelitian Sitaresmi, $\mathrm{dkk}^{(6)}$ yang menyebutkan bahwa pekerjaan ibu merupakan faktor risiko keterlambatan perkembangan anak. Anak dengan ibu yang bekerja mempunyai risiko dua kali lebih besar mengalami keterlambatan perkembangan dibanding anak dengan ibu 
yang tidak bekerja. Meskipun demikian, menurut Grantham ${ }^{(30)}$ hal yang penting bukan lama ibu bersama anak setiap hari, namun pada intensitas interaksi ibu dan anak sewaktu mereka bersama-sama. Interaksi ibu dan anak sewaktu anak makan, anak bermain maupun sewaktu ibu bekerja (di rumah) berhubungan secara positif bermakna dengan pertumbuhan dan perkembangan anak. Penelitian sebelumnya oleh Brooks-Gunn J et $\mathrm{al}^{(35)}$ menyebutkan bahwa pengaruh ibu bekerja pada kemampuan kognitif anak tergantung pada kualitas asuhan yang diterima anak di rumah maupun kualitas asuhan yang diterima anak di institusi penitipan anak/sekolah anak.

\section{KESIMPULAN DAN SARAN}

Riwayat asfiksia, riwayat gizi kurang, pemberian stimulasi perkembangan kurang dan ibu bekerja merupakan faktor risiko yang terbukti bersama-sama berpengaruh terhadap keterlambatan perkembangan anak usia balita. Disarankan untuk meningkatkan upaya deteksi dini dan penanganan keterlambatan perkembangan, pemberian stimulasi perkembangan yang baik dan meningkatkan interaksi ibu yang bekerja dengan anaknya.

\section{DAFTAR PUSTAKA}

Salkind NJ. Child Development. New York: Macmillan Reference USA; 2002.

Boyle CA, Decoufle P, Yeargin-Allsopp M. Prevalence and Health Impact of Developmental Dissabilities in US Children. Pediatrics. 1994;93(3):399403.

Alam A, Sukadi A, Risan NA, Damayanti M. Preterm and Low Birth Weight as Risk Factors for Infant Delayed Development Paediatrica Indonesiana. 2004;48(1):1-4.

Moura DR, Costa JC, santos IS, Barros AJ, Matijasevich A, Halpern R, et al.
Natural History of Suspected Development Delay Between 12 and 24 Months of Age in the 2004 Pelatos Birth Cohort Journal of Paediatrics and Child Health. 2010;46:329-36.

Peryoga SU, Sukadi A, Wiradisuria S. The Risk for Delayed Development in Low Birth Weight, Appropriate for Gestational Age Preterm Infants. Paediatrica Indonesiana. 2005;45(78):154-9.

Sitaresmi MN, Ismail D, Wahab A. Risk Factors of Developmental Delay: A Community-Based Study. Paediatrica Indonesiana. 2007;48(3):161-5.

Wilar R, Masloman N, Lestari H, Tjeng WS. Correlation between Hyperbilirubinemia in Term Infants and Developmental Delay in 2-4 Year-Old Children. Paediatrica Indonesiana. 2009;50(3):154-8.

Djuari S. Developmental Screening Test of Preeschool Age Children in Three Areas of Yogyakarta Special Region Indonesia. Berita Kedokteran Masyarakat. 1989; V(1):25-31.

Narendra MB, Suryawan A, Isa S. Perkembangan Terlambat

(Developmental Delay). Surabaya: www.pediatrik.com; 2006 [cited 2011 December 2].

Hurlock EB. Perkembangan Anak. 6 ed. Dharma A, editor. Jakarta: Erlangga; 2008.

Soetjiningsih. Tumbuh Kembang Anak. Jakarta: EGC; 2001.

Armenian HK. The Case-Control Method Design and Applications. New York: Oxford University Press; 2009.

Gordis L. Epidemiology, Fourth Edition. Philadelphia: Saunders, an imprint of Elsevier Inc; 2008.

Murti B. Prinsip dan Metodologi Riset Epidemiologi (Edisi Kedua) Jilid 
Pertama. Yogyakarta: Gadjah Mada University Press; 2003.

Sastroasmoro S, Ismael S. Dasar-dasar Metodologi Penelitian Klinis Edisi ke4. Jakarta: Sagung Seto; 2011.

.Lemeshow S, Hosmer DW, Klar J, Lwanga SK. Besar Sampel dalam Penelitian Kesehatan. Edisi Terjemah Yogyakarta:: GM Press; 1997.

Kliegman RM, Stanton BF, III JWSG, Schor NF, Behrman RE. Nelson Textbook of Pediatrics. 19 ed. Philadelphia: Elsevier Saunders; 2011.

WHO Multicentre Growth Reference Study Group. WHO Child Growth Standards: Length/height-for-age, Weight-for-age, Weight-for-length, Weight-for-height and Body mass index-for-age: Methods and Development. Geneva: World Health Organization; 2006.

Narendra MB, Sularyo TS, Soetjiningsih, Suyitno H, Ranuh I, Wiradisuria S. Buku Ajar I: Tumbuh Kembang Anak dan Remaja. Jakarta: IDAI; 2008.

BPS. Pengeluaran Rata-Rata per Kapita Sebulan untuk Makanan dan Non Makanan menurut Golongan Pengeluaran per Kapita Sebulan di Provinsi D.I. Yogyakarta 2007. Yogyakarta: BPS; 2009.

Ertem IO, Atay G, Dogan DG, Bayhan A, Bingoler BE, Gok CG, et al. Mothers' knowledge of Young Child Development in a Developing Country. Child: Care, Health and Development. 2007;33(6):728-37.

Depkes. Pedoman Pelaksanaan Stimulasi, Deteksi dan Intervensi Dini Tumbuh Kembang Anak di Tingkat Pelayanan Kesehatan Dasar. Jakarta: Depkes RI; 2005.

UGM FK, Sardjito RS. Pemantauan Perkembangan DENVER II.
Yogyakarta: Subbagian Pediatri Sosial/Tumbuh Kembang Bagian IKA/INSKA Fakultas Kedokteran UGM/RS. Dr. Sardjito2004.

Dahlan S. Statistik untuk Kedokteran dan Kesehatan, Edisi 3. Jakarta: Rineka Cipta; 2008.

Dilenge M-E, Majnemer A, Shevell MI. Long-Term Developmental Outcome of Asphyxiated Term Neonates. Journal of Child Neurology. 2001;16(11):781-92.

Haan Md, Wyatt JS, Roth S, Vargha-Khadem F, Gadian D, Mishkin4 M. Brain and cognitive-behavioural development after asphyxia at term birth. Developmental Science. 2006;9(4):4350-358.

Moster D, Lie RT, Markestad T. Joint Association of APGAR Scores and Early Neonatal Symptoms with Minor Disabilities at School Age Arch Dis Child Fetal Neonatal. 2002;86:16-21.

Elenjickal MG, Thomas K, Sushamabai S, Ahamed SKZ. Development of HighRisk Newborns - a Follow-up Study from Birth to One Year. Indian Pediatrics. 2009;46(April-17):342-5.

Grantham-McGregor S. A Review of Studies of the Effect of Severe Malnutrition on Mental Development. The Journal of Nutrition.

$1995 ; 125(8$ Supplement):2233-8.

Grantham-McGregor S, Cheung YB, Cueto S, Glewwe P, Richter L, Strupp B. Developmental potential in the first 5 years for children in developing countries. The Lancet. 2007;369(9555):60 - 70.

Mendez MA, Adair LS. Severity and Timing of Stunting in the First Two Years of Life Affect Performance on Cognitive Tests in Late Childhood. The Journal of Nutrition 1999;129:1555-62. 
Walker SP, Wachs TD, Meeks J, Lozoff B, Wasserman GA, Pollitt E, et al. Child development: risk factors for adverse outcomes in developing countries. The Lancet. 2007;369(9556):145 - 57.

Hastuti D. Stimulasi Psikososial pada Anak Kelompok Bermain dan Pengaruhnya pada Perkembangan Motoril, Kognitif, Sosial Emosi, dan Moral/Karakter Anak. Jurnal Ilmu Keluarga dan Konsumen. 2009;2(1):41-56.
Briawan D, Herawati T. Peran Stimulasi Orangtua terhadap Perkembangan Anak Balita Keluarga Miskin Jurnal Ilmu Keluarga dan Konsumen. 2008;1(1):63-76.

Brooks-Gunn J, Han W-J, Waldfogel J. Maternal Employment and Child Cognitive Outcomes in the First Three Years of Life: The NICHD Study of Early Child Care. Child Development. 2002;73(4):1052-72.

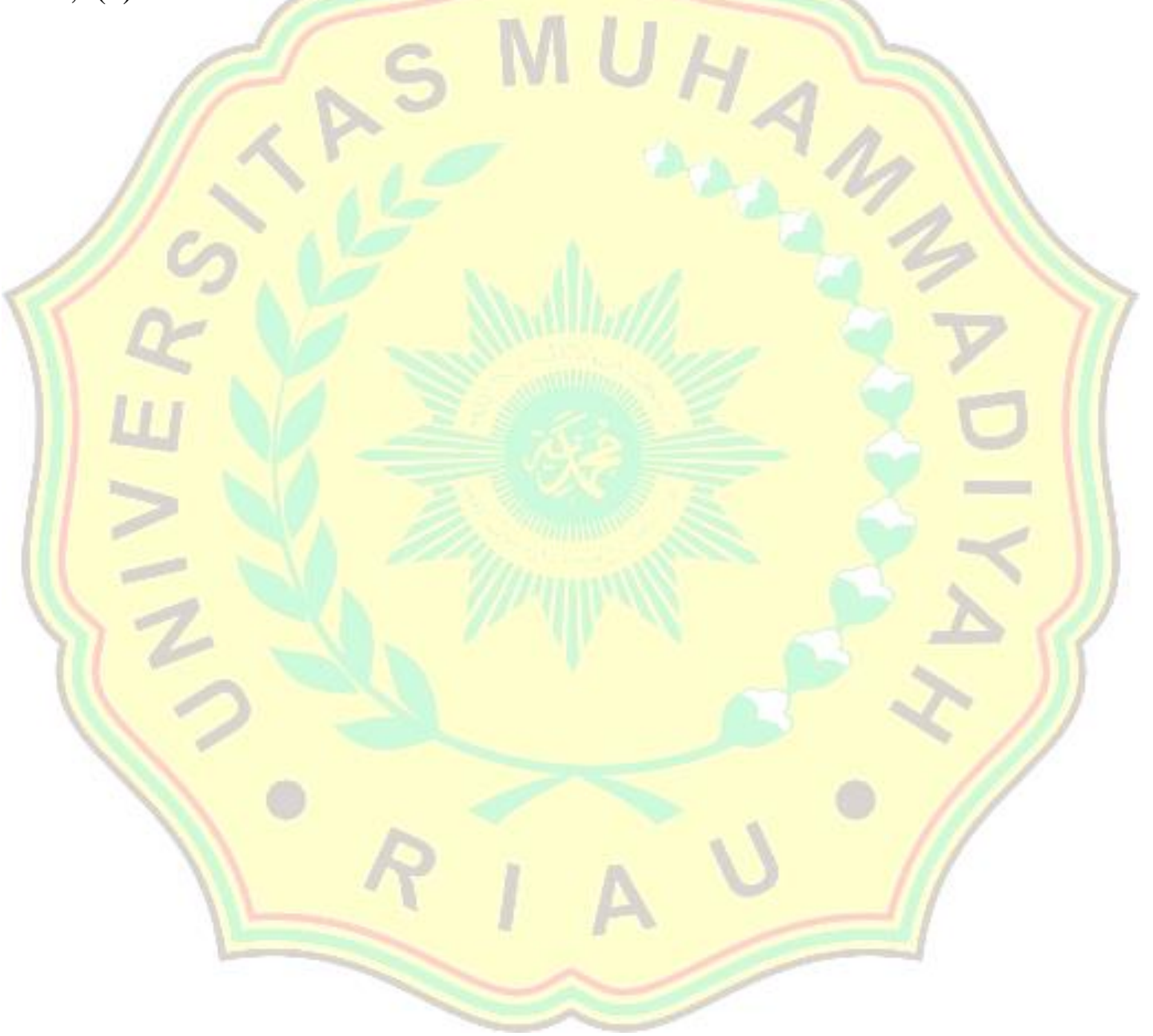

